\title{
TRANSITIONAL CONSTITUTIONALISM IN THE UNITED KINGDOM
}

\author{
Iain McLean ${ }^{*}$ \\ Scot Peterson ${ }^{\dagger}$
}

\begin{abstract}
The UK's transitional constitution dates to 1707 , when two conceptions of constitutionalism - parliamentary sovereignty and popular sovereignty-were bound together under a single government of Great Britain. Three members of one family, John MacDonald MacCormick, Professor Sir Neil MacCormick and Iain MacCormick, were instrumental in creating an environment in which it continues to change in the present day. The constitution that was proposed for Scotland in the context of the 2014 referendum included positive elements that may influence the development of the constitution of the UK, now that Scotland has chosen, at least for the short term, to remain in the union.
\end{abstract}

\section{Keywords}

Devolution, Scotland, Transitional Constitutionalism, Act of Union

\section{Introduction}

According to Joseph Raz, two characteristics of a constitution in the 'thick sense' are that it is stable, at least in aspiration, and that it is entrenched, that is, more difficult to change than other laws. ${ }^{1}$ Transitional constitutions fall short of the first requirement, because they are explicitly intended to be temporary. The UK constitution falls short of the second, at least according to traditional constitutional theory, because no law is different from any other law. In the famous words of A.V. Dicey, '[N]either the Act of Union with Scotland nor the Dentists Act, 1878, has more claim than the other to be considered a supreme law. $^{2}$

The Scottish referendum held on 18 September 2014 provides additional evidence, if any were needed, that bringing about an equilibrium in the UK's constitution will continue to be difficult (if not impossible) until the second requirement

\footnotetext{
Professor of Politics, University of Oxford.

+ Bingham Research Fellow, Balliol College, University of Oxford.

1 See J Raz, 'On the Authority and Interpretations of Constitutions: Some Preliminaries' in L Alexander Constitutionalism: Philosophical Foundations (2001).

2 A V Dicey, Introduction to the Study of the Law of the Constitution (8th ed, [1914] 1982), 78.
}

Copyright $\odot$ the Author(s).

This work is licensed under a Creative Commons Attribution-NonCommercial-NoDerivs 3.0 License. 
is met and the myth of constitutional parliamentary sovereignty has been abandoned. In this article we argue that the problem of parliamentary sovereignty has historically been and remains particularly acute in the relationship between Scotland and the rest of the UK (rUK), although other nations can feel its bite. Historically this problem has been most visible in Scotland in the relationship between church and state.

Once this general problem is recognised, solutions become easier to identify as well. What we argue is needed is an adjustment in democracy so that some items are taken off the normal political agenda and debate about them takes place only in extremis. Once structural matters, roughly the 'rules of the game', have been decided in a relatively permanent way, then other, distributional matters can be decided democratically without threatening vulnerable, marginal constituencies. Harold Lasswell defines politics as 'who gets what, when and how. ${ }^{3}$ Who gets what, when, focuses on distributional issues; how they get it is a question of constitutional law and has implications for matters as important as the West Lothian Question, defined and discussed below. We begin with a tribute to a family of constitutional iconoclasts, who helped to found the movement for Scottish independence.

\section{A Founding Family}

A key family to Scottish nationalism and therefore also to transitional constitutionalism in the UK are John MacDonald MacCormick (1904-61) and his sons Iain Somerled MacDonald MacCormick (1939-2014) and (Donald) Neil MacCormick (1941-2009). We give short biographical sketches below.

\subsection{John MacDonald MacCormick}

John MacCormick founded both the National Party of Scotland (NPS) and later the Scottish National Party (SNP) when he merged the NPS with the Scottish Self-Government Party, better known as the Scottish Party. The Scottish Party was essentially unionist, but its programme included reforming the empire and devolving home rule to Scotland, and its membership included prominent Scots such as Andrew Dewar Gibb, the Duke of Montrose and Sir Alexander MacEwan. ${ }^{4}$ Radicals in the NPS favoured republicanism and independence, and

\footnotetext{
3 H D Lasswell, Politics: Who Gets What, When, How (1936).

4 C Kidd, Union and Unionisms: Political Thought in Scotland, 1500-2000 (2008), 284-97.
} 
MacCormick expelled them in order to succeed with the merger. ${ }^{5}$ Although the new SNP was supposed to gain credibility from the grandees of the Scottish Party, it failed to win a seat in Westminster until 1945, when it briefly held one during the wartime truce among the major parties. After 1945, it had to wait until 1967, but it has been continuously represented in the UK Parliament since then.

John MacCormick had greater success with other projects, such as the Scottish convention and assembly that endorsed home rule and drafted the Scottish covenant, which evoked the Solemn League and Covenant (1643) and promoted the idea of a Scottish parliament within the United Kingdom. In addition, he was the petitioner in MacCormick v. Lord Advocate [1953] SC 396, which challenged the present queen's power to adopt the title Elizabeth II, when there had been no Elizabeth who was monarch of the nation since the union of the crowns in 1603. By this argument, Elizabeth should have been Elizabeth II of England and Elizabeth I of Scotland. Although the case seemed relatively silly even at the time and the arguments failed to convince the judges, it did elicit important obiter dicta from Lord President Cooper, which are frequently quoted in current constitutional debates:

[T] he Treaty [of Union between Scotland and England] and the associated legislation, by which the Parliament of Great Britain was brought into being as the successor of the separate Parliaments of Scotland and England, contain some clauses which expressly reserve to the Parliament of Great Britain powers of subsequent modification, and other clauses which either contain no such power or emphatically exclude subsequent alteration by declarations that the provision shall be fundamental and unalterable in all time coming, or declarations of a like effect. I have never been able to understand how it is possible to reconcile with elementary canons of construction the adoption by the English constitutional theorists of the same attitude to these markedly different types of provisions. ${ }^{6}$

5 RJ Finlay, 'MacCormick, John Macdonald (1904-1961)' in Oxford Dictionary of National Biography (2004).

6 MacCormick v Lord Advocate [1953] SC, 411. Jeffrey Goldsworthy argues that this picture of the Scottish parliament is inadequate. J D Goldsworthy, The Sovereignty of Parliament: History and Philosophy (2001), 165-73; Parliamentary Sovereignty : Contemporary Debates (2010), 270-72. We note his argument but side with Lord President Cooper and the MacCormicks on the issue. The key part of Cooper's obiter does not depend on any assumption about the pre-1707 Scottish Parliament. 
This is a powerful and historically valid argument. It may be argued that it has never had any practical consequences. It was delivered in passing, in a court that had already held against John MacCormick on other grounds. Possibly Cooper was able to be so bold just because nothing was at stake. More recent attempts to give the 'sovereignty of the Scottish people' some bite have gotten nowhere as matters of law: for instance, during the debate in early 2012 as to which Parliament had the right to commission an independence referendum with legal force. However, as Professor Aileen McHarg commented during that debate: '[Is the independence referendum] a renegotiation of Scotland's place within the union on behalf of the sovereign Scottish people (the union state narrative)?... [This] narrative ... has considerable political resonance within Scotland (whatever its historical or legal plausibility). ${ }^{, 7}$ First Minister Alex Salmond had evidently read Professor McHarg's comment when he repeatedly cited the 'sovereign will of the Scottish people' in the first 2014 referendum debate. Challenged by Better Together leader Alistair Darling as to why the remaining UK should allow an independent Scotland to share the pound sterling after independence, the First Minister's reply was that it was the sovereign will of the Scottish people that that should happen.

According to John MacCormick, sovereignty in Scotland belongs to the people. The Scottish Parliament had always been subject to the sanction of community assent, and it could not convey to the parliament of Great Britain or of the UK more power than it had itself. The UK parliament could not enjoy any greater powers than the parliament of Scotland had done, and it was 'limited by the entrenched clauses in the Treaty which had created it.'

\subsection{Professor Sir Neil MacCormick}

Donald Neil MacCormick was referred to by his middle name in order to distinguish him from his cousin the broadcaster Donald MacCormick. He held the Regius Chair of Public Law and the Law of Nature and Nations at the University of Edinburgh. ${ }^{9}$ He was a prominent member of the Scottish National Party, served as an SNP Member of the European Parliament and was important

\footnotetext{
7 A McHarg, 'Comment' on A Tomkins, The Scottish Parliament and the Scottish Referendum, 12 January 2012, at http://ukconstitutionallaw.org/2012/01/12/adam-tomkins-the-scottishparliament-and-the-independence-referendum/\#comments [accessed 30 September 2014].

8 J MacDonald MacCormick, The Flag in the Wind; the Story of the National Movement in Scotland (1955), 188-90.

9 N Walker, Sir (Donald) Neil (1941-2009) in Oxford Dictionary of National Biography (2013).
} 
in a number of cross-party initiatives in Scotland, including the Claim of Right of 1989. This, although not supported by MacCormick's party, was an important step toward devolution, realized in the Scotland Act 1998. Its title echoed the Scottish Claim of Right (1689), a more radical version of the English Bill of Rights of the same year. ${ }^{10}$ Neil MacCormick was also responsible for successive revisions to a draft constitution for Scotland and argued that an independent Scotland would automatically be a part of the European Union. ${ }^{11}$

MacCormick worried,

[I]f all legal or political power is concentrated at the level, say, of a single assembly with complete power over all matters in a large territory, then decisions affecting localities within the whole are as much subject to majority decision by the totality as decisions which have a broader, or even a holistic, scope. But the majority of the totality may be at odds with the majority in any particular locality. ${ }^{12}$

His vision was of a new legal order; in firmly established constitutional traditions he believed that multiple powers of the state were divided and that they could be subdivided further and assigned to new entities like the European Union or to subordinate entities like Scotland on a permanent, or at least indefinite, basis.

\subsection{Iain MacCormick}

Iain MacCormick is the only one of the three MacCormicks to have served as an MP in Westminster. During the parliamentary campaigns of the early 1970s Scots voters knew that North Sea Oil would be coming in, and banners claiming 'It's Scotland's Oil' were used successfully by the SNP, which gained its largest number of Westminster seats to date (11) in the election of October 1974. Iain MacCormick had served as an SNP MP for Argyllshire from February of that year, when the SNP broke through to 7 seats, and he continued to do so until 1979. That year Scotland held a referendum on devolution which was supported by $51.62 \%$ of those voting. Nevertheless, it failed to reach the $40 \%$ threshold

\footnotetext{
${ }^{10}$ R Mitchison, Lordship to Patronage: Scotland, 1603-1745 (reprinted ed 2003), 117.

${ }^{11}$ N MacCormick, Questioning Sovereignty : Law, State, and Nation in the European Commonwealth (1999), 204.

12 Ibid, 134. See also N MacCormick, 'The English Constitution, the British State, and the Scottish Anomaly' (1998) 101 Proceedings of the British Academy 289.
} 
that had been imposed by Labour backbenchers, and the Labour government fell when the SNP withdrew its support. In the meantime Iain MacCormick had pushed through the Divorce (Scotland) Act 1976 (c. 39), which had been blocked by Conservatives, who could resort to the more relaxed laws south of the border when their marriages failed..$^{13}$ Following the SNP's and Iain MacCormick's own defeat in 1979, he went on to become a Scottish founder of the Social Democratic Party, a reaction against the Labour Party's radicalization during the previous ten years. He never held political office again. But on 18 September 2014 he insisted on going to the polls to vote in person in the independence referendum despite being seriously ill. He died the following day.

John, Neil and Iain MacCormick showed that the UK is caught on the horns of a dilemma. Traditional forms of Diceyan parliamentary sovereignty bar parliament from passing laws that bind a future parliament (say, to respect Scottish political institutions) any more than any other laws (like the Dentists Act). If that principle holds, then sub-populations in the UK, like the Scots, are under the constant threat that they may be treated unequally and potentially unfairly by other, larger groups, as Neil MacCormick recognized. The only satisfactory solution to that problem for a nationally defined group is independence. If the policy alternatives are absolute, then the alternative to a constant threat from parliamentary sovereignty is to secede from the sovereign power. However, once the absolute character of parliamentary sovereignty is moderated, as Neil MacCormick proposed, then it becomes possible to have gradations of sovereignty on both sides and to have multiple legal orders. ${ }^{14}$ And the minority can have guarantees that its jurisdiction will be respected. That is exactly what devolution does.

\section{The Mixed Character of the UK Constitution}

Parts of the UK constitution meet Raz's requirement for entrenchment, even though they may not meet another of his requirements, justiciability. ${ }^{15}$ As Lord President Cooper pointed out in his judgment quoted above, parts of the Treaty of Union and the associated acts dictate that certain rules will apply in all time coming. These include the existence of the Court of Session and High Court

\footnotetext{
13 'Iain MacCormick', The Telegraph (22 September 2014)

${ }^{14}$ Compare M Malik, Minority Legal Orders in the UK: Minorities, Pluralism and the Law (2012).

${ }^{15} \mathrm{~J}$ Raz, On the Authority and Interpretations of Constitutions: Some Preliminaries' in Between Authority and Interpretation: On the Theory of Law and Practical Reason (2009) 153.
} 
of Justiciary (subject to regulations for the better administration of justice) and inferior courts; the promise 'that no alteration be made in laws which concern private right' (except for 'evident utility of the subjects within Scotland'); the existence of the universities and colleges of St Andrews, Glasgow, Aberdeen and Edinburgh; and the 'true Protestant religion' and the form and purity of worship in use within the church and 'the government of the church by kirk sessions, presbyteries, provincial synods and general assemblies. ${ }^{16}$

Although Lord President Cooper differentiated between English and Scottish jurisprudence in this respect, some English constitutional statutes also include similar language, and English constitutional theorists therefore ignore the same elementary canons of construction. The Bill of Rights, for example, contains individual rights (to be free from cruel and unusual punishment and to petition the government, for example) and includes the following clause:

[A]11 and every the particulars aforesaid shall be firmly and strictly holden and observed as they are expressed in the said Declaration And all Officers and Ministers whatsoever shall serve their Majestyes and their Successors according to the same in all times to come. ${ }^{17}$

According to this statute, ministers and officers of the crown cannot act in violation of these rights, 'in all times to come'. The quest for stability and certainty is not as alien to British or even to English law as some might like to claim.

Other provisions of the UK constitution, however, are explicitly transitional. The preamble to the Parliament Act 1911 provides,

[W] hereas it is intended to substitute for the House of Lords as it at present exists a Second Chamber constituted on a popular instead of hereditary basis, but such substitution cannot be immediately brought into operation:

And whereas provision will require hereafter to be made by Parliament in a measure effecting such substitution for limiting and defining the powers of the new Second Chamber, but it is expedient to

\footnotetext{
${ }^{16}$ Union with Scotland Act 1706, 6 Ann. c. 11; Union with England Act 1707, Acts of the Parliament of Scotland (APS) xi 406 c. 7, Records of the Parliament of Scotland (RPS) 1706/10/257 (16 January 1707), available at www.rps.ac.uk [accessed 17 October 2014].

${ }^{17}$ Bill of Rights 1688, 1 Will. \& Mary sess. 2 c. 2.
} 
make such provision as in this Act appears for restricting the existing powers of the House of Lords ... 18

In some sense this transitional constitutional provision has failed, as no popular second chamber has been brought in to operation in the past century. Nevertheless, based upon the temporary character of the restriction on the Lords' powers, Unionists proposed that George $\mathrm{V}$ withhold the royal assent from the Government of Ireland Bill because the House of Commons had been turned into a 'Revolutionary Committee. ${ }^{19}$ These arguments were put to rest by the Appellate Committee of the House of Lords in $R$ (Jackson) v Attorney General. ${ }^{20}$

Somewhere between these two poles of stability and fugacity, Scotland's current constitutional status is one of incremental entrenchment. The 1997 Scottish referendum decisively supported devolution by a vote of $74.29 \%$ with a $60.43 \%$ turnout, which would have met the threshold requirement imposed in 1979. The Scotland Act 1998 (c. 46) granted devolved powers to a Scottish parliament to be established at Holyrood. The Scots constructed a building at an eventual cost of $\mathfrak{1} 414$ million and have held elections in 1999, 2003, 2007 and 2011. Members of the Scottish Parliament (MSPs) have legislated independently on issues as vital to the nation as health care, education and infrastructure; and in 2005 powers over Scottish railways were devolved from Westminster. Disagreements between Westminster and Holyrood concerning their respective jurisdiction-that is, which matters were devolved and which reserved-can be decided by the UK Supreme Court, but to date no such dispute has reached it. ${ }^{21}$

Under the Scotland Act 2012, ${ }^{22}$ further powers will be devolved. Most importantly these include a withdrawal from 10 pence of every pound of income tax, with a corresponding reduction in the block grant calculated under the Barnett Formula. This transfer is intended to increase the financial accountability of the Scottish Parliament by forcing it to set a Scottish rate and making it responsible at the margin for deciding between taxing and spending. In spring 2014, before the referendum was held, the Scottish Labour Party proposed to increase this to 15 pence, and the Scottish Conservative and Unionist Party

\footnotetext{
${ }^{18}$ Parliament Act 1911, 1 \& 2 Geo. 5 c. 13, Preamble.

${ }^{19}$ I McLean, What's Wrong with the British Constitution? (2010) 104.

${ }^{20}$ [2005] UKHL 56. See A L Young, 'Hunting Sovereignty: Jackson v Her Majesty's AttorneyGeneral' [2006] Public Law 187.

${ }^{21}$ Scotland Act 1998, $\$ \$ 33,35$, Schedule 6.

${ }^{22}$ I McLean, G Lodge \& J Gallagher, Scotland's Choices: The Referendum and What Happens Afterwards (2nd ed, 2014) Table 3.2.
} 
proposed to devolve income tax entirely, including both the rate of tax and the bands where it increased (although not the personal allowance). ${ }^{23}$

When nations have been part of the UK and its empire in the past, the first step toward independence has frequently been statutory. Following Lord Durham's report in 1839, ${ }^{24}$ British colonies were granted self-government in Australia and Canada. In Australia, the process began in 1850, when parliament passed the Australian Constitutions Act, which separated the colonies of Victoria and New South Wales, granting them a legislative council with a majority of elected members. ${ }^{25}$ Remaining connections between Australia and the Westminster parliament (although not between Australia and the monarchy) were eliminated in 1986, when all of the Australian states, the Australian parliament and the UK parliament passed identical acts granting Australia self-government. ${ }^{26}$

In 1867 parliament passed the British North America Act, forming a federation of the provinces of Canada (later Ontario and Quebec), New Brunswick and Nova Scotia and granting them some democratic autonomy (the executive and the appointment of the upper house of the legislature remained with the crown). ${ }^{27}$ That Act, now referred to as the Constitution Act 1867 in Canada, was patriated into the constitution when the Westminster Parliament passed the Constitution Act 1982. ${ }^{28}$ Conversely, in the context of Scottish independence, Lord Hope of Craighead has argued that the precedents for granting independence lie with the Solomon Islands Act 1978 (c. 15) and the Trinidad and Tobago Independence Act 1962, 10 \& 11 Eliz. 2 c. 54. According to Lord Hope, it is up to Westminster to grant nations independence within a legal framework. ${ }^{29}$

How, if at all, can one reconcile the independence of former colonies with parliamentary sovereignty? In the 1930s, the focus was on the Statute of Westminster:

\footnotetext{
${ }^{23}$ Scottish Labour Devolution Commission, 'Powers for a Purpose: Strengthening Accountability and Empowering People' (2013), para 361, available at http://www.scottishlabour.org.uk/campaigns/entry/devolution-commission [accessed 30 September 2014]; Scottish Conservatives, 'Report of the Commission on the Future Governance of Scotland' (2013), 13 (available at http://www.scottishconservatives.com/2014/06/strathclyde-commission-scotland-fullpowers-income-tax/ (accessed 30 September 2014).

${ }^{24}$ Report on the Affairs of British North America from the Earl of Durham (3) HC PP 1839 xvii, 1.

${ }^{25}$ Australian Constitutions Act 1850, 13 \& 14 Vict. c. 59.

${ }^{26}$ Australia Act 1986 (Cth) (No 142 of 1985); Australia Act 1986 (UK) (c. 2).

${ }^{27} 30$ \& 31 Vict. c. 3.

${ }^{28}$ Canada Act 1982 (c. 11).

${ }^{29}$ House of Lords Select Committee on the Constitution, 'Inquiry into Scottish Independence: Constitutional Implications for the Rest of the UK' (2014), 60 available at http://www.publications.parliament.uk/pa/ld201314/ldselect/ldconst/188/188.pdf (accessed 17 October 2014).
} 
No Act of Parliament of the United Kingdom passed after the commencement of this Act shall extend, or be deemed to extend, to a Dominion as part of the law of that Dominion, unless it is expressly declared in that Act that that Dominion has requested, and consented to, the enactment thereof. ${ }^{30}$

Here, the UK is promising that before it legislates for dominions like Canada and Australia it will request and obtain the consent of the dominion: as happened with both the Canada Act 1982 and the Australia Acts 1986. Lord Sankey wrote of this section:

It is doubtless true that the power of the Imperial [i.e. Westminster] Parliament to pass on its own initiative any legislation that it thought fit extending to Canada remains in theory unimpaired; indeed, the Imperial Parliament could, as a matter of abstract law, repeal or disregard section 4 of the Statute. But that is theory and has no relation to realities. ${ }^{31}$

So, too, with Scotland. Section 28(7) of the Scotland Act says that the section, which grants to Scotland the power to make laws, 'does not affect the power of the Parliament of the United Kingdom to make laws for Scotland.' The constitutional scholar Anthony Bradley has written, '[A]s a matter of strict law, Westminster retains full capacity to amend or repeal the Scotland Act and may do so at any time, without any prior procedure such as a referendum of the Scottish Electorate being necessary. ${ }^{32}$ This is why the dilemma that the MacCormicks identified matters to Scotland. Anthony Bradley has also written, 'Westminster retains full capacity to legislate on any aspect of Scotland's affairs, whether or not they are within Edinburgh's legislative competence, but [echoing Lord Sankey,] as a matter of political practice Westminster will legislate on devolved matters only with the approval of the Scottish Parliament. ${ }^{33}$

\footnotetext{
${ }^{30}$ Statute of Westminster 1931, $22 \& 23$ Geo. 5 c. $4, \$ 4$.

${ }^{31}$ British Coal Corp v The King [1935] AC 500.

${ }^{32}$ A Bradley, 'The Sovereignty of Parliament-Form or Substance?' in J L Jowell and D Oliver (eds), The Changing Constitution (2011), 53.

${ }^{33}$ Ibid. This 'political practice' is reinforced by the Sewel Convention and by the rules, including the standing orders in the Holyrood parliament that guide its operation. See Report of the Commission on Scottish Devolution, 'Serving Scotland Better: Scotland and the United Kingdom in the $21^{\text {st }}$ Century' (June 2015), paras 1.159-1.166, 1.170-1.171, 2.17-2.18.
} 
The dilemma remains. In strictly legal terms, Scottish law is subordinate to the majoritarian decision-making process in Westminster, even if, according to Lord Sankey and Anthony Bradley, those decisions are practically constrained by 'reality' and 'political practice'. But what assurance do the Scots have that the reality of political practice will not change, or be slowly undermined by future Westminster parliamentary majorities? It has happened before, as we discuss below.

\section{The Problem of Religious Freedom and Religious Establishment}

Following the flight of James II and VII in 1688, the so-called Glorious Revolution began with convention parliaments in England and Scotland, which both invited William of Orange and his wife Mary to reign. William and Mary assumed the English throne on 12 February 1688/89, but the Scottish throne was not offered until 11 April, and on different terms. Succession planning depended upon William having children, either with his wife Mary or with another queen, or upon Mary's sister Anne doing so. None of them did, so the succession was uncertain. ${ }^{34}$ The English passed the Act of Succession in 1701, establishing the Hanoverian succession (which meant the crown passed to George I via his mother, Sophia, electress of Hanover) without consulting the Scots. Meanwhile, the Scots had embarked upon the romantically conceived but disastrous Darien Expedition to establish a colonial presence in Central America. Its failure was a result of poor planning (few knew what the geography would be like), bad strategy (the nearby Spanish colonies were held by William's ally in his European wars) and William's interdict of finance from London. It resulted in the loss of $£ 153,631$ by the Scots-estimated to be one-fourth of the nation's capital stock. ${ }^{35}$ Finally, the English Parliament was forced to accept concessions to the Scots in order to finance William's military campaign in Europe, but it retaliated with the Alien Act, which restricted trade in cattle, linen and coal: 'a naked piece of economic blackmail designed to bring the Scottish Parliament swiftly to the negotiating table. ${ }^{36}$

\footnotetext{
${ }^{34}$ J Hoppit, A Land of Liberty?: England, 1689-1727 (2002), 37. Hoppit writes that William's 'health and inclination' were against remarriage-an allusion to William's rumoured homosexuality.

${ }^{35}$ I McLean and A McMillan, State of the Union (2005), 39-41.

${ }^{36}$ T M Devine, The Scottish Nation, 1700-2000 (1999), 3.
} 
The events of 1707 have been examined in detail elsewhere, but the Scots were not defenceless when they came to the bargaining table. Amongst other things, they could credibly threaten to offer the Scottish throne to the Stuarts, and they did so with an Act for the Security of the Kingdom, which held out the possibility that the union of the English and Scottish crowns might be at risk. ${ }^{37}$ The best evidence that they actually exercised this leverage was the concessions that they were able to extract in the treaty, including the preservation of the Scottish legal system, universities and church. ${ }^{38}$ However, once the union was complete, the English Parliament's commitment to preserve the church was not as credible as Scotland's threat had been in the Union negotiations. In March 1710, the House of Lords decided Greenshields $v$ Lord Provost and Magistrates of Edinburgh, ${ }^{39}$ which permitted an episcopal minister to conduct services in Edinburgh-across the street from the High Kirk (St Giles); and the following year Parliament passed the Scottish Episcopalians Act $1711{ }^{40}$ legally authorising such services. These abrogated the treaty provision that 'presbyterian government' would be 'the only government of the church within the kingdom of Scotland'. The coup de grâce was delivered that same year, when parliament passed the Church of Scotland (Patronage) Act, which restored the ability to appoint clergy to lay patrons, rather than kirk sessions and presbyteries. ${ }^{41}$ The act implicitly repealed the Act concerning Patronages, ${ }^{42}$ thereby violating the commitment that the 'government' of the Church would 'remain and continue unalterable'.

Lord Rodger of Earlsferry points out that although church leaders argued that the Patronage Act was incompatible with the guarantees of the Treaty of Union, Scottish lawyers and judges of the time did not challenge it. ${ }^{43}$ But Lord Rodger's point is a broader one. When the London-based judiciary and courts breached the promises in the treaty, they created an environment that led to the Disruption of 1843, which was the culmination of 'the most sustained challenge to its authority which the [Scottish] Court of Session has ever faced'. ${ }^{44}$ From 1711 until 1784 the General Assembly sent protests to Parliament, arguing that the Patronage Act

\footnotetext{
${ }^{37}$ APS xi 136 c. 3; RPS 1704/7/68 (5 August 1704).

${ }^{38}$ Text accompanying note 16 , above.

39 [1710] Colles 427, 1 ER 356.

4010 Ann. c. 10.

${ }^{41} 10$ Ann. c. 21

${ }^{42}$ APS ix 196 c. c. 53 ; RPS 1690/4/114.

${ }^{43}$ A Rodger of Earlsferry, The Courts, the Church and the Constitution: Aspects of the Disruption of 1843 (2008) 5-7.

${ }^{44}$ Ibid, 80 .
} 
was a violation of Scottish religious self-determination and should be repealed. ${ }^{45}$ During that time, too, numerous divisions occurred in the Scottish Church, first when the Associate Presbytery withdrew from the Church of Scotland, then when the Relief Church withdrew. The Associate Presbytery divided into Burghers and Anti-Burghers, based on whether its clergy could take the Burgher Oath following the rebellion of 1745 , and in the early nineteenth century each of those divided into Auld Licht and New Licht sections. At one point in the early 1800s, seven presbyterian denominations existed in Scotland. ${ }^{46}$ The biggest division in the Church of Scotland occurred over a measure introduced by a resurgent evangelical wing: the Veto Act, which imposed a congregational veto over the patron's choice of a congregation's minister. After a decade of litigation, in which the courts refused to give effect to the act, in 1843 some one-third of the clergy and between one-third and one-half its members withdrew to form the Free Church of Scotland in the Disruption. ${ }^{47}$

As other markets generally clear, so too with religious markets. If there are too many providers, then they must merge in order to be profitable, or even survive. Between the 1840s, when the Relief Church joined with the New Lichts to form the United Presbyterian Church, and the 1890s, these denominations slowly consolidated until only four or five remained. ${ }^{48}$ These included the United Presbyterian Church, the Free Church and the Church of Scotland. When the first two merged in 1900, to form the largest anti-establishment religious denomination in Great Britain, a minority in the Free Church stayed out and sued in the civil courts, arguing that the majority had violated central doctrinal tenets upon which the church had been founded. Although the Scottish courts uniformly supported the Free Church against the dissentient minority, the House of Lords, in its judicial capacity, repeated the mistake that Parliament and the House of Lords had made in 1710-11. They intervened on a point of doctrine and awarded all of the Free Church's assets to a group of twenty-seven congregations and twenty-eight ministers, predominantly in the Highlands and Islands, since

\footnotetext{
45 J H S Burleigh, A Church History of Scotland (1960) 278-79.

${ }_{46}$ These were the original Church of Scotland, its predecessor, the Reformed Presbyterian Church (the Covenanters, who remained from the time of the Wars of the Three Kingdoms), the Constitutional Associate Presbytery (Auld Licht, Antiburgher); the General Associate Synod (New Licht Antiburgher); the Associate Synod (New Licht Burgher); and Original Burgher Synod (Auld Licht Burgher), alongside the Relief Church.

${ }^{47}$ A O’Neill, 'The Courts, the Church and the Constitution Revisited,' in A S Burrows, D Johnston, and R Zimmermann, Judge and Jurist: Essays in Memory of Lord Rodger of Earlsferry (2013).

${ }^{48}$ In addition to those mentioned above, the Reformed Presbyterians retained their independence, and the Free Presbyterian Church withdrew from another church when it changed its oath.
} 
known as the Wee Frees. ${ }^{49}$ Three government commissions were necessary to sort out the property, and the largest denomination that opposed religious establishment in Scotland was critically wounded. ${ }^{50}$ In 1909 formal negotiations began concerning a merger between the new United Free Church and the Church of Scotland. ${ }^{51}$ However, prerequisite to this union, legislation was necessary to ensure that the new church would be free from parliamentary or judicial interference.

The 1921 act - the Church of Scotland Act - was the result. It provided in part:

This Church... [has] the right and power subject to no civil authority to legislate, and to adjudicate finally, in all matters of doctrine, worship, government, and discipline in the Church, including the right to determine all questions concerning membership and office in the Church, the constitution and membership of its Courts, and the mode of election of its office bearers, and to define the boundaries of the spheres of labour of its ministers and other office-bearers. ${ }^{52}$

This independence went unchallenged until the twenty-first century, when the Appellate Committee of the House of Lords decided Percy $v$ Board of National Mission of the Church of Scotland [2005] UKHL 73, which held that Helen Percy, a Church of Scotland minister, could sue the church under the Sex Discrimination Act 1975 (c. 65), notwithstanding the provisions of the Church of Scotland Act 1921.

Lord Rodger, as Lord President of the Court of Session, had decided the case in favour of the Church of Scotland, based upon the fact that Ms. Percy was not employed under a contract. He writes, 'I confess that I was glad to decide the case on that basis and to be relieved of the need to deal with the Church's first argument': that the Church of Scotland deprived the civil courts of jurisdiction. ${ }^{53}$ He argues that Percy was a significant development in an area of the law which

\footnotetext{
${ }^{49}$ See Church and Creed in Scotland: The Free Church Case 1900-1904 and Its Origins (1988).

${ }^{50}$ Sir John Cheyne, 'Interim Report to the Rt Hon the Marquess of Linlithgow, KT, His Majesty's Secretary for Scotland' P.P. 1905 ci, 727 (Cd 2510); 'Report of the Royal Commission on Churches (Scotland)' P.P. 1905 xxiii, 113 (Cd. 2494); 'Report of the Royal Commission Appointed under the Churches (Scotland) Act, 1905’ P.P. 1910 xiii, 343 (Cd. 5061).

${ }^{51} \mathrm{~J}$ H S Burleigh, A Church History of Scotland (1960) 399-400.

${ }^{52}$ Church of Scotland Act 1921, 11 \& 12 Geo. 5 c. 29, Schedule Art. IV.

${ }^{53}$ A Rodger of Earlsferry, The Courts, the Church and the Constitution : Aspects of the Disruption of $1843(2008) 92$.
} 
many people hoped had been settled once for all when Parliament passed the Church of Scotland Act 1921. ${ }^{54}$ The lawyer Aidan O'Neill generalises further, in spite of the court's holding in Percy:

[T]he Church of Scotland Act 1921 now regulates the relationship between Church and State in Scotland. ... But at times it seems as though the Erastian monist assumptions underpinning only the Anglican settlement have been regarded by the courts (and by our lawmakers) as the sole approach constitutionally open to them. ${ }^{55}$

O’Neill also brings Neil MacCormick back into the picture, referring to Lord Rodger's perspective on Percy as that of an 'Insider-Outsider' whose Scottish Presbyterian background had sensitised him to a different 'political theology' from his London-trained judicial colleagues. ${ }^{56}$ Drawing on MacCormick's conception of a 'hermeneutic viewpoint', from which a sympathetic but dispassionate observer seeks to understand a legal order different from her own, O'Neill argues that Lord Rodger's respectful treatment of the Church of Scotland in his own judgment in Percy arose from his dual identity as a Scot and an internationalist.

As one of us has pointed out, the British Constitution is like a series of train crashes. ${ }^{57}$ Since 1840 railway accidents in the UK have been inspected by HM Inspectorate of Railways, whose inspector reports recommend safety improvements to prevent a repetition of the accidents. This series of train crashes over Scottish religious freedom, established (Church of Scotland) and non-established (United Free Church) alike, should not go unmarked when anticipating future Anglo-Scottish relations, as Scotland remains in the continuing United Kingdom. Indeed, as we have both argued elsewhere, the complete solution to this tension between religious belief and the law may require a binding promise to respect religious freedom throughout the $\mathrm{UK}^{58}$

\footnotetext{
${ }^{54} \mathrm{Ibid}, 94$.

${ }^{55}$ A O'Neill, 'The Courts, the Church and the Constitution Revisited' in A Burrows, D Johnston, and R Zimmermann, Judge and Jurist (2013) 643.

${ }^{56}$ Ibid, 649-51.

${ }^{57}$ I McLean, What's Wrong with the British Constitution?, 44; I McLean and C Foster, 'The Political Economy of Regulation: Interests, Ideology, Voters, and the UK Regulation of Railways Act 1844' (1992) 10(3) Public Administration 313.

${ }^{58}$ I McLean and S Peterson, 'Entrenching the Establishment and Free Exercise of Religion in the Written UK Constitution' (2011) 9(1) Int J of Const L 230.
} 


\section{The Problems Posed by the Reaffirmed Union}

\subsection{A Co-operative Process}

Getting Scotland and rUK to where they are now has required cooperation from the governments in both Westminster and Holyrood. In particular, the Edinburgh Agreement of 2012 committed both the Scottish and UK Governments to accepting the result of the referendum, and

to working together on matters of mutual interest and to the principles of good communication and mutual respect. The two governments have reached this agreement in that spirit. They look forward to a referendum that is legal and fair producing a decisive and respected outcome. The two governments are committed to continue to work together constructively in the light of the outcome, whatever it is, in the best interests of the people of Scotland and of the rest of the United Kingdom. ${ }^{59}$

Although the agreement had no legal effect on its own, it gained that effect through a statutory instrument. ${ }^{60}$ In the Solomon Islands an oil shock made it clear that continued colonial status became financially unfeasible from 1973, and in Trinidad and Tobago, 20 of 30 members of the legislature, who were members of the nationalist People's National Front, pushed for independence. On independence day Princess Margaret read the queen's message relinquishing her rule. However, cooperation in Scotland was not foreordained. Between 1885 and 1918 an overwhelming majority of Irish MPs in Westminster supported Home Rule, but they were unsuccessful. A.V. Dicey, the architect of parliamentary sovereignty in its modern form, abandoned his own doctrine in favour of the view, in opposition to successive Government of Ireland Bills, that those bills could only become law if they were ratified in referenda-and perhaps not even then. ${ }^{61}$ That the Generalitat of Catalunya voted in September 2014 to hold a

\footnotetext{
${ }^{59}$ HM Government and The Scottish Government, 'Agreement between the United Kingdom Government and the Scottish Government on a Referendum on Independence for Scotland' (15 October 2012), Art 30 <http://www.scotland.gov.uk/Resource/0040/00404789.pdf> [accessed 18 October 2014].

${ }^{60}$ Scotland Act (Modification of Schedule 5) Order 2013 (S.I. 2013 No. 242). Confusingly, although this is a Section 30 Order, the reference is not to Article 30, quoted above, but to section 30 of the Scotland Act 1998 (c. 46).

${ }^{61}$ I McLean, What's Wrong with the British Constitution? (2010), 142-54.
} 
referendum on secession from Spain has not impressed either the Spanish federal government or the nation's constitutional court. ${ }^{62}$

The Anglo-Scottish experiment with national self-determination has been a more harmonious process so far. The Scottish government published its Scottish Independence Bill in the months before the election, and the interim constitutional provisions in that document have a distinctly Cooperite tone-one that both Lord Rodger and the MacCormicks would have recognized. It is no longer than that masterpiece of Enlightenment lucidity, the constitution of the United States of America. It also shares intellectual history with the US constitution, opening with the statement, 'In Scotland, the people are sovereign.' ${ }^{63}$ It thereby repudiates parliamentary sovereignty and embodies the work of Lord President Cooper and Neil MacCormick. At the same time, it set limits to that sovereignty, imbuing the European Convention on Human Rights with constitutional force: much stronger protection than the statutory force the convention enjoys in $\mathrm{rUK}^{64}$

\subsection{Institutional Adjustments}

Currently a commission is investigating other ways that power can be devolved to Scotland consistently with the 'vow' made by the Westminster party leaders two days before the election. That vow makes the constitution of the UK more of an interim constitution than it has been in decades, if not centuries. Panicked by polls in the weeks before the referendum, which had shown a closer race than actually occurred, all three leaders of the main Westminster parties signed a pledge in the days before the election, which was published in the Daily Record, the most widely read Scottish newspaper. ${ }^{65}$ It said, 'The Scottish Parliament is permanent and extensive new powers for the Parliament will be delivered by the process and to the timetable agreed and announced by our three parties ...66

${ }^{62}$ A Kassam, 'Catalonia Independence Referendum Halted by Spain's Constitutional Court,' The Guardian (29 September 2014), <http://www.theguardian.com/world/2014/sep/29/cataloniaindependence-referendum-spain-court-vote $>$ [accessed 18 October 2014].

${ }^{63}$ Scottish Government, "The Scottish Independence Bill: A Consultation on an Interim Constitution for Scotland' (2014), Art 2 <http://www.scotland.gov.uk/resource/0045/00452762.pdf> [accessed 18 October 2014].

${ }^{64}$ Ibid, Art 26(1).

${ }^{65}$ N Blain and D S Hutchison, The Media in Scotland (2008), 228. The Murdoch Scottish Sun surpasses the Daily Record in circulation, but it cannot be called a 'Scottish' newspaper in the pure sense of the term, as it is the Scottish edition of an English paper.

${ }^{66}$ Daily Record, 16 September 2014 <http://www.dailyrecord.co.uk/news/politics/davidcameron-ed-miliband-nick-4265992> [accessed 18 October 2014]. 
Prime Minister David Cameron appointed Lord Smith of Kelvin, a cross-bench member of the House of Lords, to head the commission to agree on what additional powers would be devolved.

However, in his speech on 19 September, following the Scottish voters' decision to remain in the union, Cameron announced:

[J]ust as Scotland will vote separately in the Scottish Parliament on their issues of tax, spending and welfare, so too England, as well as Wales and Northern Ireland, should be able to vote on these issues and all this must take place in tandem with, and at the same pace as, the settlement for Scotland. ${ }^{67}$

Interpretations conflict, but this statement appears to make the Scottish Parliament's extensive new powers contingent on agreement about English votes for equivalent matters in England. Numerous difficulties arise from this proposal, which seeks to solve the West Lothian Question ('WLQ'). The WLQ, strictly speaking, asks why MPS (and potentially peers) from one country should vote one way on a policy that affects only that country but be out-voted by MPs from other nations in the UK. Before 1997 WLQs occurred primarily on non-English laws. The Poll Tax, introduced in Scotland only by an act which the majority of Scottish MPs opposed; Welsh church reform, blocked by English MPs (and peers) before 1914; coercion acts in nineteenth century Ireland; and the Patronage Act (Scotland), 1711/12 (discussed above) are all instances of WLQs. Although reform of the Church of England's prayer book in 1927-28, supported by English MPs, was blocked by MPs from outside England where the church is not established, more modern instances of English misfires include four votes on hospital and higher education funding in 2003-04. A growing plurality of people want to see English Votes on English Laws, to curtail or eliminate the risk of this occurring in the future. ${ }^{68}$

Several alternatives are available, but not all are politically feasible. One neat one is to establish regional governments in England, in standard regions that

\footnotetext{
${ }^{67}$ D Cameron, 'Scottish Independence Referendum: Statement by the Prime Minister' (19 September 2014), <https://www.gov.uk/government/news/scottish-independence-referendumstatement-by-the-prime-minister> [accessed 18 October 2014].

${ }^{68}$ Report of the Commission on the Consequences of Devolution for the House of Commons (2013), at Tables 1 and 4 <http://webarchivenationalarchives.gov.uk/20130403030652/http://tmc.independent.gov.uk/wp-content/uploads/2013/03/The-McKay-Commission_Main-Report_25-March-20131.pdf> [accessed 18 October 2014].
} 
are roughly equivalent in population and GDP to Scotland, Wales and Northern Ireland. However, this one was scuttled when it was defeated in a referendum in the Northeast of England in 2004. ${ }^{69}$ A second alternative is an English Parliament; however, such a legislature would include $85 \%$ of the UK's population and would destabilise the union. The McKay Commission, which reported in 2013, proposed a double-count of English MPs: '[T]he determining majority would be that in the overall vote [of all UK MPs], as has always been the case. ${ }^{, 70}$ However, that vote would be preceded by one in an English Grand Committee, which would have to approve English-only legislation before it could proceed. The report continues, 'But if a government was seen to have failed to attract the support of a majority of MPs from England (or England-and-Wales) for business affecting those interests, it would be likely to sustain severe political damage. ${ }^{, 71}$

There are two crucial problems with this proposal. Gladstone recognised the first in the context of Irish MPs remaining in the House of Commons after Home Rule: '[I]t passes the wit of man' to define the territorial scope of a bill. ${ }^{72}$ In addition, this is a soft constraint. When parliamentary stakes are high enough, a determined government with tough whips would know that votes on a particular bill are subsumed by noise at election time. The 2003-04 votes on foundation hospitals and tuition fees did not decide the 2005 election.

This leaves a final option: a reduction in the number of Scottish and other nations' MPs, to reduce the likelihood that their votes will be decisive on English laws. This is the option that Gladstone proposed in his abortive 1893 Government of Ireland Bill. Gladstone's caustic colleague Sir William Harcourt retorted that fifty MPs may be as decisive as 100 and that 'you don't get rid of the [interference] any more than the young woman did of the baby by saying it's such a little one'. However, the probability of fifty MPs being decisive is almost always less than half that of 100 MPs being decisive. ${ }^{73}$ Thus, Gladstone's 1893 proposal is probably the most realistic one.

${ }^{69}$ For more information, see <http://www.electoralcommission.org.uk/_data/assets/pdf_file/0008/76994/NEreffullreport.pdf> [accessed 23 October 2014].

${ }^{70}$ McKay Commission, above n 68, para 219.

71 Ibid.

72 Gladstone MSS, BL Add. Mss 44672 f. 27, quoted in V Bogdanor, Devolution in the United Kingdom (1999) 30. See e.g. R Morris, 'Deliver us from EVEL? - a side-effect of the devolution debate' (20 October 2014) <http://constitution-unit.com/2014/10/20/deliver-us-from-evel/> [accessed 20 October 2014], observing that even the Church of England's Bishops and Priests (Consecration and Ordination of Women) Measure is not purely an English law, because it amends the UK-wide Equality Act 2010.

${ }^{73}$ D Felsenthal and M Machover, The Measurement of Voting Power (1998), Ch 2. 


\subsection{Emergent Fiscal Federalism}

The main issue for Lord Smith's commission is how much tax should be devolved; devolution of spending responsibilities is secondary (although spending rather than taxing is the focus of almost all debate). Now that the voters have decided against independence (for the present), the Scotland Act 2012 will come into effect. This means that the Scottish Parliament will become more fiscally responsible. It will have to balance the delights of public spending against the discipline of raising tax to pay for it. The Scottish election campaigns of the future may not repeat those of 2007 and 2011, when every Scottish party promised to tax less and spend more than its rivals. The 2012 Act was constitutionally novel in that it was passed with the approval of both parliaments-in Westminster and Holyrood. Further taxing and spending powers, beyond those in the 2012 Act, will undoubtedly be devolved, as agreed by the Westminster parties in advance of the referendum and now embodied in the 'vow' described above. At a minimum, the devolution of housing benefit and accommodation allowance makes sense in light of the fact that other housing expenditures are devolved. ${ }^{74}$

Fiscal federalism is difficult, because two inconsistent objectives are at issue. On the one hand is self-determination. Local populations may have different priorities. In one geographic area, the population (and its majority political party) may put greater importance on spending, for example, for health, education or infrastructure such as roads or bridges, and in another part of the country low taxes may be more important, for example to attract businesses. But on the other is equity, because this leads to what newspapers refer to as the 'post-code lottery', where benefits or taxes depend upon the seemingly arbitrary criterion of where the boundary is drawn. This difference can seem particularly inequitable when the geographic line seems particularly arbitrary, as when the line divides London councils.

The Calman Commission, whose recommendations were largely adopted in the Scotland Act 2012, distinguished between fiscal policies that should remain UK-wide and those that could be devolved. ${ }^{75}$ Devolved taxes have the potential

\footnotetext{
${ }^{74}$ HM Government, 'The Parties' Published Proposals on Further Devolution for Scotland' (Cm 8946), October 2014, 34-35<https://www.gov.uk/government/uploads/system/uploads/attachment_data/file/363236/Command_paper.pdf> [accessed 19 October 2014]. This command paper is simply a reiteration of what has already been promised by the parties independently.

${ }^{75}$ Calman Commission on Scottish Devolution, Scotland Better: Scotland and the United Kingdom in the $21^{\text {st }}$ Century Final Report, 15 June $2009<\mathrm{http}$ //www.commissiononscottishdevolution.org.uk/uploads/2009-06-12-csd-final-report-2009fbookmarked.pdf> [accessed 19 October 2014].
} 
to add costs to the system, including increased cost of administration by the government and additional compliance costs to individuals and businesses. Calman offered the principle, going back to Adam Smith, that the best taxes to devolve are those on bases that do not move, such as land and unextracted oil. The worst are corporate taxes, as international businesses can instantly pretend to do business in low-tax jurisdictions. VAT may not be devolved within an EU member state.

\subsection{How to Make These Decisions}

Alan Renwick, in a pamphlet published before the independence referendum, predicted, "Whether Scots vote "Yes" or "No", the referendum will generate a need for careful thought about major constitutional questions. ... The time will be opportune for encouraging a national conversation about the future form of the Union. ${ }^{76}$ He goes on to describe the experiences of other nations with constitutional conventions, including the manner of choosing the representatives, the way that they should be charged with a remit, and the manner of their deliberation. A constitutional convention has been called for by Unlock Democracy, the Electoral Reform Society and the Commons Political and Constitutional Reform Committee. It has also been supported by the Labour, the Liberal Democrats, the Green Party and the United Kingdom Independence Party. And in the week before we write the Conservative Party leader in charge of this question has said that the government would consider these proposals. ${ }^{77}$

Robert Hazell has recently urged caution. ${ }^{78}$ First, he argues, if issues like House of Lords reform, devolution and the UK's voting system have proved intractable on their own, they may well be insurmountable in a convention. Second, timing issues will dominate any discussion of how to decide. No convention could take place before the general election scheduled for May 2015, so support for one at this point is cheap talk. According to Hazell's sample, the normal lead-up time to establishing a convention is six months, and if the governing party and other parties engage in preliminary negotiations, that period can extend to two years. How might this fit with the current proposal by the

\footnotetext{
${ }^{76}$ A Renwick, After the Referendum: Options for a Constitutional Convention (2014).

${ }^{77}$ HC Hansard, vol. 586, col. 179, 14 October 2014 (William Hague).

${ }^{78}$ R Hazell, 'You Want a Constitutional Convention? This is What You Need to Think Through First', 8 October 2014, <http://constitution-unit.com/2014/10/08/you-want-a-constitutionalconvention-this-is-what-you-need-to-think-through-first/> [accessed 18 October 2014].
} 
Conservatives to hold an in-out referendum on the EU in 2017 and even with the Scottish elections in May 2016?

These questions are not idle ones, although Renwick's argument in support of a carefully chosen convention, with both citizens' and legislators' participating and a broad remit that can be extended, seems plausible and is supported by evidence. Renwick believes that a wide range of issues can be dealt with by a carefully selected group of citizens and legislators, with support from experts, and that outcomes might help resolve difficult questions in UK politics, and not only those relating to Scotland. These could indeed include reform of the House of Lords, the WLQ, and a voting system, which gives the Conservatives just one MP in Scotland despite the fact that they received $20 \%$ of the vote there in the last general election.

To return to earlier analogies from this article, cooperation will be necessary if these issues are to be resolved in this way. The process must be more like the one that led up to the referendum and not like the one that nearly led to civil war in 1914, when opponents of Home Rule allowed that anything was permitted in their efforts to keep the Union together. Each of the parties will have to adopt Neil MacCormick's hermeneutic viewpoint if the process is to succeed. It will also be necessary to take note of earlier train crashes, so that lessons can be learned and the potential for another one can be averted. Finally, the myth of parliamentary sovereignty must be abandoned and the ability of Parliament to bind its successors, which dates back at least to 1689 in England and to 1707 in Scotland, must be respected. Only then will the Parliament in Westminster be able to learn the lesson taught by the MacCormicks and Lord President Cooper: that commitments can be useful at protecting those who most desire, and need, protection.

\section{Conclusion}

The UK is at a constitutional moment. ${ }^{79}$ Whatever the outcome, as to which one may be less optimistic than Renwick, the last vestiges of Diceyanism have gone. The Scottish Parliament is embedded in the UK constitution, and future constitutional change in the country will require its assent. More prosaically, fiscal responsibility is on its way, which may put limits on the fantastic promises hitherto made by politicians in parliaments that spend but do not tax. Within weeks of his party's referendum defeat, the Scottish Finance Minister introduced

\footnotetext{
${ }^{79}$ See B Ackerman, We the People: Foundations Vol 1 (1991).
} 
Scotland's first new local tax for three centuries - an ad valorem tax on property transactions in place of the appalling UK Stamp Duty Land Tax. ${ }^{80}$ We take that as a hopeful sign.

${ }^{80}$ Scottish Parliament, Official Report 9 October 2014. <http://www.scottish.parliament.uk/parliamentarybusiness/28862.aspx?r=9570\#.VDuiVldvBpQ> [accessed 13 October 2014]. For the appallingness of SDLT, see S Adam, 'Fundamentally flawed', Financial Times, 22 February 2013 $<$ http://www.ifs.org.uk/publications/6619> [accessed 20 October 2014]. 